\title{
The Effect of Atrophic Rhinitis on Growth Rate
}

\author{
By Karen J. Baalsrud
}

\begin{abstract}
Baalsrud, K. J.: The effect of atrophic rhinitis on growth rate. Acta vet. scand. 1987, 28, 299-304. - Growth rate in pigs with turbinate atrophy was compared to growth rate in pigs without turbinate atrophy in 9 herds with atrophic rhinitis (AR) in which toxigenic strains of Pasteurella multocida had been isolated. Average reduction in growth rate in pigs with severe turbinate atrophy was $4.7 \%$ as compared to pigs without turbinate atrophy. The difference was statistically significant only in some herds. Pigs with moderate AR gained on average $1.1 \%$ less than unaffected ones. Thus, the study supports the assumption that AR is of economic significance in modern pig farming.
\end{abstract}

pigs; toxigenic Pasteurella multocida.

\section{Introduction}

It is now accepted that toxin produced by certain strains of Pasteurella multocida is the main virulence factor in the development of persistent atrophic rhinitis (AR) in pigs. The toxin is supposed to be a growthretarding factor because of its influence on fast-growing bone structures (Elling \& $\mathrm{Pe}$ dersen 1985). Though bone structures throughout the body can be affected, changes are most easily observed in the snout, which is characterized by a particularly intense osseous metabolism (Martineau-Doizé \& Martineau 1986). Nevertheless, diverging results have been obtained from investigations on the effect of AR on weight gain.

It is also accepted that both Bordetella bronchiseptica and P. multocida may produce AR alone or together, though the severe and persistent $A R$ associated with growth retardation seems to be dependent on the presence of toxigenic P. multocida.
Challenge experiments have shown that toxigenic P. multocida has a specific influence on the growth of bone cells (Elling \& Pedersen 1983). It therefore seemed of interest to ascertain whether the presence of toxigenic $P$. multocida and reduction in weight gain in AR pigs could be demonstrated under field conditions.

In the present study, weight gain was related to pathoanatomical AR changes at slaughter in herds in which bacteriological investigations revealed the presence of toxigenic P. multocida. The aim was furthermore to evaluate the economic significance of AR due to reduced weight gain under field conditions.

\section{Materials and methods \\ Herds}

Nine combined herds (i.e. herds containing both breeding sows and slaughter pigs), from which toxigenic P. multocida had been isol- 
ated, were included in the study. They were situated in various parts of south-eastern and south-western Norway. Clinical problems associated with AR existed in all herds, though to various degrees. Environmental conditions, and thus the general health situation, also varied from herd to herd. The 9 herds also participated in a vaccination experiment in which 2 vaccines containing P. multocida/B. bronchiseptica bacterins were tested for their effect against AR (Baalsrud 1987). Apart from this, no special measures, such as medication programmes, were introduced in any of the herds with regard to controlling AR.

Altogether 711 fattening pigs were included, all Norwegian Landrace. They were marked individually at weaning in order to allow identification at slaughter.

\section{Pathoanatomical investigations}

At slaughter, all snouts were sectioned transversely at the level of the first premolar teeth to investigate the nasal turbinates for atrophic changes. Findings were graded as follows: $0=$ normal turbinates, $1=$ moderate turbinate atrophy, and $2=$ severe, i.e. almost total or total, turbinate atrophy. When tur- binate atrophy on the 2 sides of the nasal cavity varied, the most extensive changes were registered. The investigations were carried out at 4 different slaughterhouses. Each person recording findings was supplied with a figure of snout sections to allow visual comparison and standardization of results (Fig. 1).

\section{Weight gain}

The slaughter weight of the dressed carcass was recorded for each pig and divided by the age of the pig in days to obtain the average daily weight gain. For each herd, the average daily weight gain of pigs without turbinate atrophy was set to be $100 \%$.

\section{Observations in the herds}

All herds were visited before the observation period started. Any clinical signs of AR observed were graded as follows: $1=$ one or very few pigs showing twisted or shortened snouts, 2 = one or more pigs in several litters showing twisted or shortened snouts, and $3=$ severely affected individuals with deformed snouts and nosebleeding, and most of the litters affected.

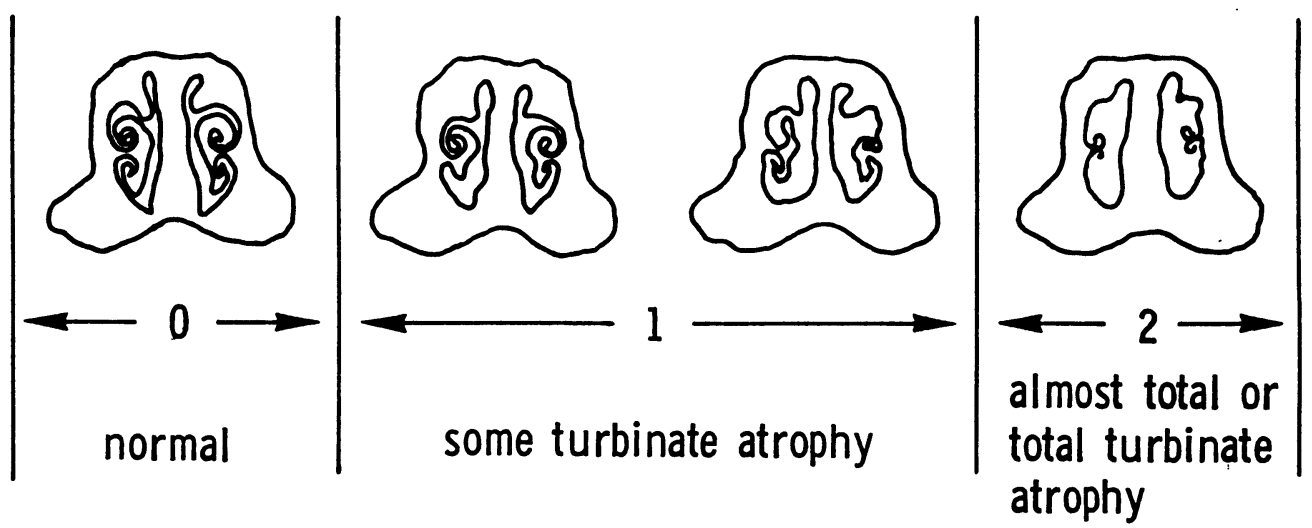

Figure 1. Visual guide to gradation of turbinate atrophy in snout sections at the level of the first premolar teeth. 
Bacteriological and toxinological investigations

Nasal swabs were taken from piglets before weaning at the beginning of the observation period. Between 4 and 36 swabs were taken from each herd and investigated bacteriologically for the presence of P. multocida. The swabs were transported to the laboratory in phosphate-buffered saline and inoculated onto blood agar plates containing 2 $\mu \mathrm{g}$ clindamycin per ml. After $24 \mathrm{~h}$ incubation at $37^{\circ} \mathrm{C}$ mucoid, pink-greyish single colonies were selected and subcultivated on blood agar plates. Pure cultures were identified as P. multocida by standard procedures, including indol production and fermentation of dextrose, saccharose, lactose, raffinose and rhamnose. Isolates of P. multocida were subjected to further investigation using the hyaluronidase method (Carter \& Rundell 1975) and the acriflavine flocculation method (Carter \& Subronto 1973), and identified as serotypes $A$ and $D$. They were tested for toxin production by the guinea pig skin test (Jong 1980) and by a cell culture assay using a primary culture of embryonic bovine lung cells as described by Rutter \& Luther (1984).

\section{Statistical analyses}

A Student's t-test was performed on each of the AR groups against the non-AR group on the weight gain results.

\section{Results}

\section{Pathoanatomical findings}

At slaughter, turbinate atrophy was found in 9 to $79 \%$ of the pigs from each herd. Table 1 shows the percentage of pigs in each herd showing no turbinate atrophy, moderate AR and severe $A R$, respectively. On average, $43 \%$ showed no pathoanatomical changes in the nasal turbinates. $43 \%$ had moderate turbinate atrophy, while in $14 \%$ atrophy of the nasal turbinates was severe or total.

Table 1. Weight gain in slaughter pigs with moderate and severe turbinate atrophy compared to pigs without turbinate atrophy in the same herd.

\begin{tabular}{lrccccccc}
\hline Herd & $\begin{array}{c}\text { No. of } \\
\text { animals }\end{array}$ & $\begin{array}{c}\text { Clinical } \\
\text { AR }\end{array}$ & $\begin{array}{c}\text { \% of animals } \\
\text { with no AR }\end{array}$ & $\begin{array}{c}\text { \% weight gain } \\
\pm \text { SD }\end{array}$ & $\begin{array}{c}\text { \% of animals } \\
\text { with mo- } \\
\text { derate AR }\end{array}$ & $\begin{array}{c}\text { \% weight gain } \\
\pm \text { SD }\end{array}$ & $\begin{array}{c}\text { \% of animals } \\
\text { with } \\
\text { severe AR }\end{array}$ & $\begin{array}{c}\text { \% weight gain } \\
\pm \text { SD }\end{array}$ \\
\hline 1 & 48 & 2 & 29 & $100 \pm 8.8$ & 58 & $94.8 \pm 10.3$ & 13 & $92.6 \pm 12,9$ \\
2 & 66 & 2 & 64 & $100 \pm 12.1$ & 24 & $102.3 \pm 11.1$ & 12 & $94.7 \pm 20.5^{*}$ \\
3 & 108 & 3 & 91 & $100 \pm 10.9$ & 3 & $99.5 \pm 4.0$ & 6 & $94.8 \pm 7.2$ \\
4 & 84 & 3 & 34 & $100 \pm 11.1$ & 43 & $99.5 \pm 10.3$ & 23 & $101.5 \pm 17.1$ \\
5 & 90 & 2 & 34 & $100 \pm 10.2$ & 55 & $102.9 \pm 10.2$ & 11 & $95.1 \pm 12.9^{*}$ \\
6 & 76 & 3 & 21 & $100 \pm 9.9$ & 47 & $98.1 \pm 17.1$ & 32 & $89.8 \pm 27.2^{* *}$ \\
7 & 105 & 2 & 34 & $100 \pm 8.5$ & 56 & $100.3 \pm 11.6$ & 10 & $94.7 \pm 19.5^{*}$ \\
8 & 64 & 2 & 39 & $100 \pm 16.4$ & 52 & $100.2 \pm 16.4$ & 9 & $91.1 \pm 23.2^{* *}$ \\
9 & 70 & 3 & 37 & $100 \pm 12.7$ & 50 & $101.1 \pm 14.0$ & 13 & $103.3 \pm 16.6$ \\
\hline Total & & & 43 & 100 & 43 & 98.9 & 14 & 95.3 \\
\hline
\end{tabular}

1 See text for gradation.

* Statistically significant $(p<0.05)$

** Statistically significant $(\mathrm{p}<0.005)$ 


\section{Weight gain}

Weight gain in pigs with severe turbinate atrophy was, on average, $95.3 \%$ compared to pigs without turbinate atrophy, the corresponding figure for pigs with moderate AR being $98.9 \%$ (Table 1). In 7 of 9 herds the average daily weight gain in pigs with severe turbinate atrophy was reduced by 5 to $10 \%$ as compared with normal pigs. In herds 4 and 9, pigs with severe AR did not show reduced growth compared to unaffected pigs (Fig. 2). These 2 herds were both troubled by periodic outbreaks of acute pneumonia, and overall average weight gains were lower than in any of the other herds. Growth rate in the different herds should, however, not be compared as nutritional and environmental factors were not standardized.

There seemed to be no relationship on a herd basis between reduction in growth rate and the percentage of pigs in the herd with registered turbinate atrophy. Reduction in

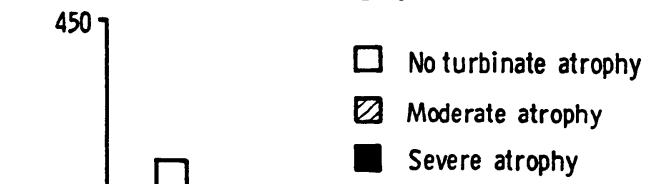

weight gain in pigs with AR was not related to the AR vaccination status of the sow, through the frequency of AR was slightly lower in the vaccination groups (Baalsrud 1987).

\section{Observations in the herds}

In all 9 herds a number of pigs showed definite symptoms of $A R$, and thus none of these could be classified as having clinical AR grade 1 (Table 1). In 5 herds $(1,2,5,7$ and 8), pigs in several litters showed signs of AR, though there were few with severely deformed snouts, and nosebleeding was usually absent. In the other 4 herds, $(3,4,6$ and 9) most litters were affected, severely deformed snouts were seen more often and nosebleeding was observed regularly.

Herds 4 and 9 suffered periodic outbreaks of acute pneumonia that necessitated treatment with antibiotics. Pneumonia was not a clinical problem in any of the other herds.

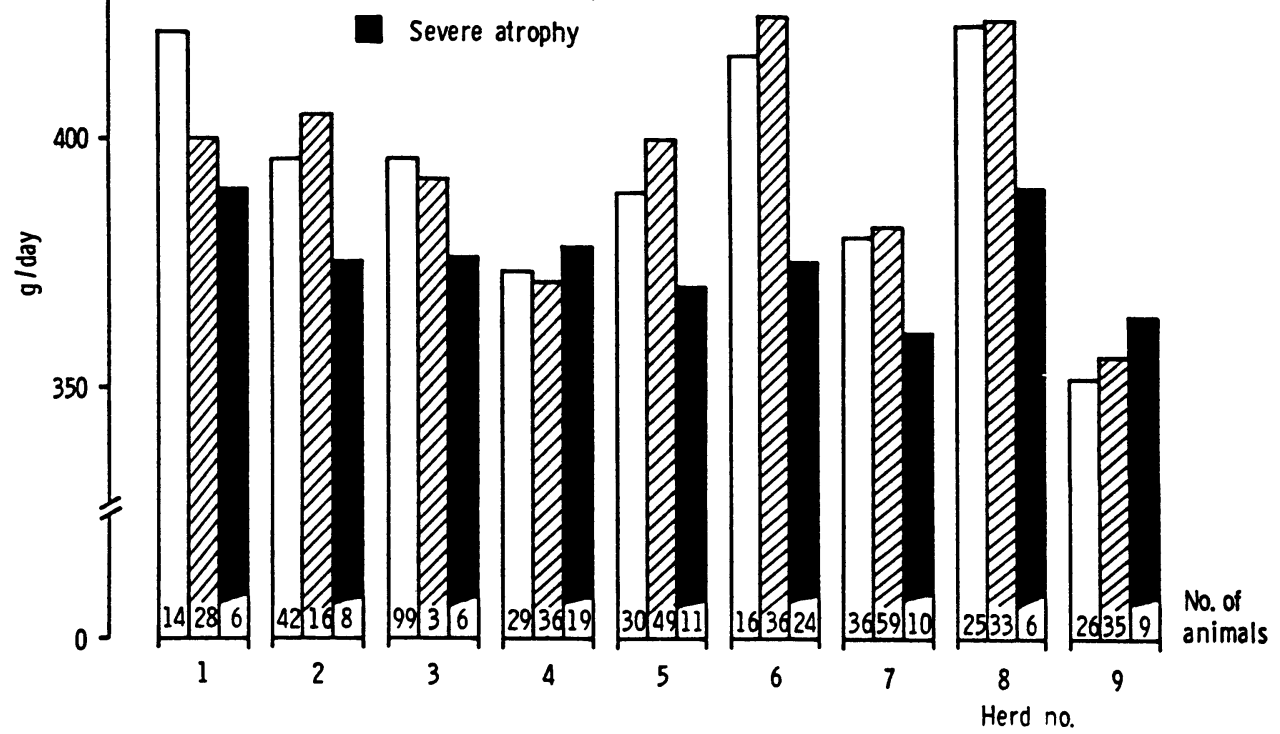

Figure 2. Daily weight gain related to turbinate atrophy at slaughter. 


\section{Bacteriological and toxinological investigations}

Toxigenic strains of P. multocida were isolated from 7 of the 9 herds. In each of the remaining 2 herds, ( 4 and 5), only 4 nasal swabs were taken and the few isolates of P. multocida obtained were found to be toxin-negative. There is reason to believe that toxigenic strains might well have been isolated if more comprehensive investigations had been carried out, as persistent AR was present in both of these herds.

\section{Discussion}

The $4.7 \%$ reduced growth in pigs with severe $\mathrm{AR}$ as compared to non-AR pigs is about the same value as that found by $P e$ dersen \& Barfod (1981) in a challenge experiment, and also corresponds well with the findings of Giles et al. (1980) and Bäckström et al. (1982 and 1985) in field studies.

Bäckström et al. (1982) and Straw et al. (1984) found no correlation between AR and pneumonia, though in the latter study pneumonia was found to reduce the growth rate. Morrison et al. (1985) found a low, positive correlation between individual scores of turbinate atrophy and the associated percentage of lung involved with pneumonia. In the present study, the 2 herds in which pigs with severe AR did not show reduced weight gain compared to the pigs without AR, had both suffered regular outbreaks of acute pneumonia, and in both these herds weight gain was generally low. Pneumonia can also result in low weight gains and this may explain why AR did not seem to influence weight gain in these 2 herds.

The infectious agents B. bronchiseptica and P. multocida can produce turbinate atrophy either alone or in combination. However, the production of severe, persistent turbinate atrophy is dependent on the presence of toxigenic strains of P. multocida (Rutter 1985).
Such turbinate atrophy is also associated with changes in bone tissue which may result in growth retardation. Yoshikawa \& Hanada (1981) found definite signs of chondrolytic and necrotic changes in the matrix of the epiphyseal cartilage throughout the body in spontaneous cases of AR.

In the present study, the reduction in growth rate in AR pigs did not seem to be related to the severeness of the clinical signs of AR in the herd. A definite reduction was also seen in herds with a stable AR situation without marked clinical symptoms. This may support the hypothesis that it is the infectious agent(s) which is (are) responsible for the reduced weight gain, and that environmental factors play only a minor role as long as toxigenic strains of $P$. multocida are present.

As reduction in growth rate in AR pigs seems unrelated to the overall clinical picture in the herd or the frequency of turbinate atrophy found at slaughter, losses due to AR in a herd may be estimated on the basis of the number of pigs affected. Based on the findings on this study, the following estimations can be made: As fattening pigs put on roughly $1 \mathrm{~kg}$ body weight per day during the immediate pre-slaughter period, and are slaughtered at approximately $100 \mathrm{~kg}$ live body weight, pigs with moderate AR will need about 1 more day to compensate the $1.1 \%$ reduced growth rate. On the same basis, pigs with severe AR will need about 5 more days in order to reach normal slaughter weight. The cost of these extra days in terms of feed and housing will vary from herd to herd. Nevertheless, the findings in this study provide a tool with which one may calculate the extra costs which the pig industry must bear because of AR.

\section{Conclusion}

Even though the observed reduction in growth rate was not statistically significant 
in all herds, the present study supports that $\mathrm{AR}$ is of economic significance in modern swine production. The data obtained in this study may also provide a basis on which to evaluate the benefit to be gained by the introduction of immunoprophylactic measures against the disease.

\section{References}

Bäckström L, Hoefling DC, Morkoc AC, Cowart $R P$ : Effect of atrophic rhinitis on growth rate in Illinois swine herds. J. Amer. vet. med. Ass. 1985, 187, 712-715.

Bäckström L, Hoefling D, Morkoc A, Vinson R, Smith AR: Atrophic rhinitis in swine I: Clinical signs, slaughter lesions, daily weight gain, disease transmission. Int. Pig. Vet. Soc. Congr., Mexico 1982, p. 116.

Baalsrud KJ: Vaccination against atrophic rhinitis: Effect on clinical symptoms, weight gain and turbinate atrophy. Acta vet. scand. 1987, 28, 305-311.

Carter GR, Rundell $S W$ : Identification of type A strains of P. multocida using staphylococcal hyaluronidase. Vet. Rec. 1975, 96, 343.

Carter GR, Subronto P: Identification of type D strains of Pasteurella multocida with acriflavine. Amer. J. vet. Res. 1973, 34, 293-294.

Elling $F$, Pedersen KB: Atrophic rhinitis in pigs induced by a dermonecrotic type A strain of Pasteurella multocida. In: Atrophic rhinitis, eds. K. B. Pedersen \& N. C. Nielsen. CECreport EUR 8643 En. Office for Official Publications of EEC, Luxembourg 1983, p. 123135.

Elling $F$, Pedersen $K B$ : The pathogenesis of persistent turbinate atrophy induced by toxigenic Pasteurella multocida in pigs. Vet. Pathol. 1985, 22, 469-474.

Giles CJ, Smith IM, Baskerville AJ, Brothwell E: Clinical bacteriological and epidemiological observations on infectious atrophic rhinitis in pigs in southern England. Vet. Rec. 1980, 106, 25-28. de Jong MF, Oei HL, Tetenburg GJ: AR-pathogenicity-tests for Pasteurella multocida isolates. Proc. Int. Pig Vet. Soc. Congr. Copenhagen 1980, p. 211.

Martineau-Doizé B, Martineau GP: Topography and differential growth of the nasal ventral concha (os conchae nasalis ventralis) of the pig from birth to six weeks of age. Amer. J. vet. Res. 1986, 47, 416-421.

Morrison RB, Hilley HD, Leman AD: The association between pneumonia and atrophic rhinitis in slaughter weight swine. Canad. vet. J. 1985, 26, 95-97.

Pedersen KB, Barfod $K$ : The aetiological significance of Bordetella bronchiseptica and Pasteurella multocida in atrophic rhinitis of swine. Nord. Vet.-Med. 1981, 33, 513-522.

Rutter JM: Atrophic rhinitis in swine. Adv. Vet. Sci. 1985, 29, 239-279.

Rutter JM, Luther PD: Cell culture assay for toxigenic Pasteurella multocida from atrophic rhinitis of pigs. Vet. Rec. 1984, 114, 393-396.

Straw BE, AD Leman, Robinson RA: Pneumonia and atrophic rhinitis in pigs from a test station - a follow-up study. J. Amer. vet. med. Ass. 1984, 185, 1544-1546.

Yoshikawa T, Hanada T: Histopathological studies on pigs with atrophic rhinitis showing retarded growth. Jpn. J. vet. Sci. 1981, 43, 221 -231 .

\section{Sammendrag}

Atrofisk rhinitts innvirkning på tilveksthastighet.

Tilveksten hos griser med og uten concha-atrofi ble sammenlignet i 9 besetninger som alle hadde klinisk nysesjuke og hvor toksinproduserende stammer av Pasteurella multocida var påvist. Griser med uttalt concha-atrofi vokste i gjennomsnitt $4,7 \%$ seinere enn griser uten tryneforandringer $i$ samme besetning, mens griser med moderat concha-atrofi hadde gjennomsnittlig $1.1 \%$ nedsatt tilvekst. Selv om reduksjonen i tilvekst ikke var statistisk signifikant $i$ alle besetninger, bekrefter dette at nysesjuke medfører økonomiske tap i moderne svinehold.

(Received March 16, 1987).

Reprints may be requested from: Karen J. Baalsrud, National Veterinary Institute, P O Box 8156 Dep, N-0033 Oslo 1, Norway. 